\title{
A Special Public Relations Opportunity for Academic Libraries
}

\author{
Jon Eldredge \\ Library Director \\ Eastern New Mexico University \\ Clovis Campus
}

The Gustavus Adolphus College Library, St. Peter, Minnesota, has been selected as one of the winners of the 1982 John Cotton Dana Public Relations Award. Four academic libraries participated in the contest this year which had a total of 154 entries. In its brief existence the friends group for the library, the Gustavus Library Associates, raised over $\$ 400,000$ toward building a library endowment of more than $\$ 1$ million. The endowment was created to build the library's collection and to help qualify the college for gaining a Phi Beta Kappa chapter on campus.

The John Cotton Dana Public Relations Award grants recognition to those libraries that have exhibited excellence in their public relations activities during the past year. All sizes and types of libraries, media and information centers are eligible to enter the contest. All entries are reviewed by a committee of public relations experts representing many different types of libraries. ${ }^{1}$ Normally the committee includes at least one academic librarian. Each year the committee examines approximately 150 entrants, selects the winner, and designates the recipient of special awards. The committee makes its decisions on the basis of the public relations activities of participating libraries rather than on the basis of just the publicity component of these activities. The H.W. Wilson Company and ALA's Library Administration and Management Association have jointly sponsored the award since 1946 . The contest was established at that time to honor the career of John Cotton Dana (1856-1959), a vigorous advocate of library public relations.

In recent years academic librarians have become increasingly aware of the important role played by public relations in the process of effective library management. Many academic librarians would probably find that Dana's philosophy on public relations closely resembles their own views on the subject. Yet in his time, Dana's philosophy was not always respected by his peers in the profession. Dana was a great innovator in librarianship at the turn of the century, but his unique contribution to the field was his insistence upon the importance of library promotion. In 1910 he used a billboard to encourage use of the Denver Public Library. The

The committee consists of members of the Public Relations Section of ALA's Library Administration and Management Association (LAMA). use of the billboard shocked a number of librarians, since up until that time no one had really "advertised" libraries. ${ }^{2}$

During his busy career Dana served as ALA president and was one of the principal founders of the Special Library Association. He was a public librarian during most of his career. His involvement with public libraries may in part explain why the number of entries from public libraries in the John Cotton Dana Public Relations Award contest dwarfs the number of entries from academic libraries. Only four academic libraries entered the contest in 1982 and only five entered in 1981. In those same years, there were 76 and 57 entries respectively from public libraries.

For whatever reason, it seems unfortunate that the library profession perceives the contest to be a public library activity when all libraries are eligible to compete. When they have entered the contest, academic libraries have done well in acquiring awards-since 1970 twenty-two academic libraries have been recognized by the awards committee, and five of these were award winners.

There are two distinct categories of awards made by the judging committee: the winners and the special awards. Winners are honored for an overall library public relations program which has consistently followed a single theme over the course of a calendar year. About four of these awards are selected from all entries submitted to each contest. This category takes into consideration all activities, budget expenditures, and planning connected with a year-long public relations effort.

One of the 1981 award winners, the J. Paul Leonard Library at San Francisco State University, directed its program toward the education of library users about a new automated circulation system. Focusing on a zebra theme to represent the new bar code identification system, the library hung large, colorful banners at the entrance to the building and carried out a series of carefully planned activities both inside the library and around campus during the year. The program was very successful in introducing the new system to the campus community.

The University of Texas Library won an award for its comprehensive set of publications intended to promote the library in 1977. The preceding year the University of Utah Library won an award for its effective and creatively produced student orientation program.

"Peggy Barber, "Public Relations," in the ALA World Encyclopedia of Library and Information Services (Chicago: American Library Association, 1980), p. 460 . 


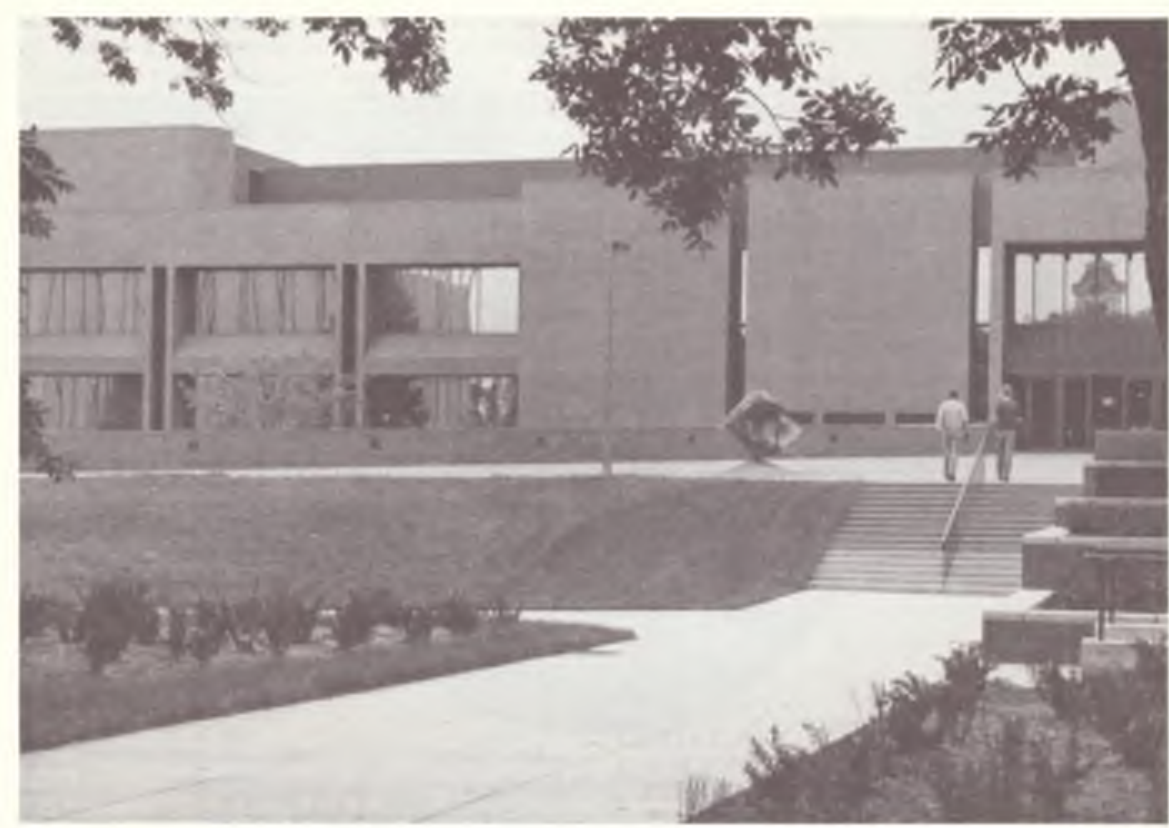

The Folke Bernadotte Memorial Library, Gustavus Adolphus College, St. Peter, Minnesota, 1982 John Cotton Dana Public Relations Award winner.

The John Cotton Dana Public Relations Award also involves a number of special awards each year. The judging committee selects 16-24 awards in this category for each contest. The majority of academic libraries receiving awards in the past decade have done so in this category. Special awards give recognition to single public relations projects which meet with great success in achieving a planned goal. In this category the Gustavus Adolphus College Library (also a 1982 award winner) won a special award for its fund-raising efforts in 1978 aimed at increasing library acquisitions. In 1979 the University of Oklahoma Health Sciences Center Library also received a special award for its technically sophisticated videotape orientation project that made use of special visual effects.

Other recipients of special awards in past years have been the University of Houston Library in 1970 for its high-quality publications which brought special attention to a collection of rare books: the University of Denver Library for its focus on a library exhibit on Native Americans in 1975; and the Allegany Community College Library, Cumberland, Maryland, for its 1976 promotion of a local oral history project.

No guarantee exists that an academic library will receive either type of award for any particular year. In both 1969 and 1980, for example, no award was presented to an academic library. In contrast, the 1975 award decisions produced two award winners and three special awards for academic libraries. On the average, the judging committee receives very few academic entries each year. In 1982 only $3 \%$ of the total entries submitted came from academic libraries.

In the past, entries to the contest for both categories have usually consisted of a scrapbook containing photographs, newspaper clippings, library brochures, and other relevant material pertaining to the library's public relations project. A growing number of entries are supplemented by or made up entirely of nonprint materials such as videotape. Darrel Hildebrandt, who has chaired the John Cotton Dana Award Committee for the past two years, estimates that $20 \%$ of the entries in recent years have included nonprint formats. As a matter of fact, three of the five entries from academic libraries in 1981 consisted of nonprint materials.

In judging the contest, the committee pays special attention to the quality rather than the quantity of materials submitted. Committee member Dale Carrison thinks libraries should not be concerned about spending large amounts of money on production of programs or projects. The Dyke College Library, Cleveland, won an award in 1971 specifically because it had few financial or personnel resources available to allocate in what turned out to be a very successful public relations program. In addition to quality, the committee considers the amount of creativity reflected by entries 
to be an important factor in selecting award recipients.

The committee looks for specific, measurable outcomes that can be attributed to the success of the participating libraries' public relations activities. Libraries need to clearly demonstrate how they evaluated the success of their program in reaching goals and objectives. The amount of care and time devoted to the planning process also ranks as an important consideration. Entries should possess an organized, clear presentation of the theme of the public relations program or project. Finally, entries should relate to recent activities.

An information brochure and an application form can be obtained from Patricia Sabosik, Director of Marketing Services, H.W. Wilson Company, 950 University Avenue, Bronx, NY 10452. The brochure outlines some of the basic guidelines for entering the contest. The next deadline for entry forms is January 3, 1984, and the deadline for scrapbooks and nonprint materials is February 6, 1984. Scrapbooks and nonprint entries for winners of both categories of the award are on display in the exhibit area at ALA Annual Conference. The same materials are available for two years after the announcement of award winners via interlibrary loan from ALA Headquarters Library.

Academic libraries involved with public relations activities which they believe to be exciting and well managed should certainly consider entering the John Cotton Dana Public Relations Award contest. In looking back on the performance of academic libraries that have secured awards and comparing it to the relatively small number of academic entries submitted, college and university librarians may well wish to take advantage of this special opportunity for our area of librarianship.

\section{DOUGHERTY NAMED LIBRARIAN OF THE YEAR}

Richard M. Dougherty, director of the library at the University of Michigan, Ann Arbor, has been awarded the ACRL Academic or Research Librarian of the Year Award for 1983. The Association of College and Research Libraries and the Baker \& Taylor Company will present the award to Dougherty on June 27 at the ACRL reception at Annual Conference in Los Angeles.

The award cites Dougherty for his involvement in the editing of professional journals, especially College \&

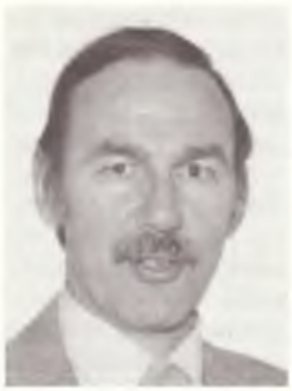

Richard M. Dougherty Research Libraries (1969-1974) and the Journal of Academic Librarianship (since 1975), but also including Library Resources and Technical Services, the LibraryCollege Journal, and the Journal of Library Automation.

Dougherty was also cited for his achievements as a library administrator at the University of Michigan, the University of California, Berkeley, and the University of Colorado. "In a short span of time," the citation reads, "Richard M. Dougherty, library administrator, editor, and educator, has left his mark on academic librarianship and the library profession through his prolific writings, able administration and committed professional involvements."
An especially noteworthy accomplishment was at Berkeley, where he played a leading role in a cooperative program to make the resources of the research libraries at UC-Berkeley and Stanford University available to the faculty and graduate students of both institutions.

Dougherty's publications include five monographs, two of the most recent being the widely cited Improving Access to Library Resources and a second edition of Scientific Management of Library Operations, co-authored with Fred J. Heinritz. The wide range of his articles, reports, editorials and reviews is indicative of Dougherty's intellectual capacity and variety of interests in the library profession.

The recipient of the Esther J. Piercy Award and a fellowship from the Council on Library Resources, Dougherty has also found time to teach future librarians at seven library schools. He has also served on the American Library Association's Executive Board, ALA Council, the Board of Directors of the Association of Research Libraries, and has been an active member of ACRL.

The ACRL Academic or Research Librarian of the Year Award was established by ACRL and the Baker \& Taylor Company to recognize individual members of the library profession who have made outstanding national or international contributions to academic or research librarianship and library development. The award consists of $\$ 2,000$ and a citation.

Recipients of the award since its inception in 1978 have been: Keyes D. Metcalf and Robert B. Downs (1978); Henriette D. Avram and Frederick G. Kilgour (1979); Evan I. Farber (1980); Beverly P. Lynch (1981); and William Stone Budington (1982). 




\section{YOU'LLADVANCE CONFIDENTLY IN THE WORLD OF TECHNOLOGY ..WHEN YOUR ON-LINE SYSTEM IS BASED ON LIBRARY KNOWLEDGE}

Baker \& Taylor's LIBRIS II On-Line Acquisitions System represents state-of the art technology coupled with 155 years of library experience

Only Baker \& Taylor can offer o complete acquisitions system featuring:

- electronic ordering from the nation's largest stock of books

- a 700.000+ title database

- automatedopen-order contro

- aufomated fund accounting

For defails, contact the Soles Department of the division nearest you. UBRIS II, only from Baker \& Taylor:

EASTERN , SO Kirtby Avenue, Somerville, NJ 08870. (201) 722-8000 MIDWESTERN, 501 S. Glodiolus Street. Momence, Il cops4, [815] 472-2444 SOUTHERN Mi. Olive Rood. Commerce, GA 30590 (404) 335.5000 WESTERN, 380 Edison Way. Reno, NV 80564, (702) $786-6700$ 